\title{
FAKTOR YANG MEMPENGARUHI TINGKAT NYERI ANAK USIA 7-13 TAHUN SAAT DILAKUKAN PEMANSANGAN INFUS
}

\author{
Nur Ilah Padhila ${ }^{1}$, Anjasari Jusmani² \\ nurilah.padhila@umi.ac.id \\ jusmanianjas@gmail.com \\ ${ }^{1,2}$ Fakultas Kesehatan Masyarakat, Universitas Muslim Indonesia
}

\begin{abstract}
ABSTRAK
Dalam tahap pertumbuhan dan perkembangannya, anak tidak selalu berada padakondisi kesehatan yang optimal tetapi senantiasa berada pada rentang sehat maupun sakit. Beberapa penyakit yang diderita akan menyebabkan anak harus mengalami perawatan di Rumah Sakit dan seringkali menjadi masalah karena anak yang dirawat harus memperoleh tindakan sesuai dengan kebutuhannya, salah satunya adalah pemasangan infus. Tujuan penelitian ini adalah untuk mengetahui faktor yang mempengaruhi tingkat nyeri anak usia 7-13 tahun saat di lakukan pemasangan infus di RSUD Kota Makassar.Penelitian ini adalah penelitian kuantitatif dengan rancangan Cross Sectional Study.Penelitian ini dilakukan pada semua anak usia 7-13 tahun di RSUD kota makassar yang mengalami tindakan pemasangan infus dan yang pernah mengalami pemasangan infus sebelumnya dengan jumlah sampel 30 anak. Hasil penelitian menunjukkan tidak ada pengaruh jenis kelamin terhadap tingkat nyeri anak usia 7 13 tahun saat pemasangan infus. Namun, ada pengaruh pengalaman sebelumnya dan pendampingan orang tua terhadap tingkat nyeri anak usia 7-13 tahun saat pemasangan infus.
\end{abstract}

Kata kunci : Pemasangan Infus, Tingkat Nyeri

\section{ABSTRACT}

In its development and development, children are not always in optimal health conditions but always in a healthy range. Some of the illnesses suffered will cause child care in the hospital and the problems that the child problems have verified must be in accordance with their needs, one of which is the installation of an IV. The purpose of this study is to study the factors that influence the level of difficulty of children 7-13 years when installing infusions in Makassar City Hospital. This research is a quantitative study by designing a Cross Sectional Study. This research was conducted on all children aged 7-13 years at Makassar City Hospital that improves the installation of infusion and who has previously installed infusion with a sample of 30 children. The results showed no variation in types compared with children aged 7-13 years when installing the infusion. However, there is the benefit of previous experience and parental assistance on the level of safety of children aged 7-13 years when placing infusion.

Keywords: Infusion Installation, Pain level

\section{PENDAHULUAN \\ Latar Belakang}

Masa anak-anak merupakan masa awal dalam kehidupan seseorang. Penyesuaian yang terjadi pada masa dewasa dipengaruhi oleh masa kanak-kanak, artinya pengalaman baik dan tidaknya seorang anak akan menetukan tingkah lakunya pada saat dewasa (Marimbi, 2010). Dalamtahap pertumbuhan dan perkembangannya, anak tidak selalu berada padakondisi kesehatan yang optimal tetapi senantiasa berada pada rentang sehat maupun sakit(Hidayat, 2005).Beberapa penyakit yang diderita akan menyebabkan anak harus 
mengalami perawatan di Rumah Sakit dan seringkali menjadi masalah karena anak yang dirawat harus memperoleh tindakan sesuai dengan kebutuhannya, salah satunya adalah pemasangan infus.

Prosedur pemasangan infus merupakan tindakan invasif yang sering diberikan pada setiap pasien, tak terkecuali pasien anak (Wang, Sun, \& Chen, 2008). Tindakan pemasangan infus akan menimbulkan rasa nyeri, dimana nyeri merupakan suatu perasaan yang tidak nyaman yang dialami oleh seseorang (Andarmoyo, 2013) dan merupakan sumber utama distres pada anak, keluarga maupun petugas kesehatan (Kyle \& Carman, 2012).Respon verbal pada anak sangat berbeda dengan orang dewasa dalam mengungkapkan rasa nyeri yang dialami, Halini membutuhkan pengkajian yang baik saat menilai nyeri karena akan menetukan jenis terapi yang efektif. Salah satu metode penilaian intensitas nyeri dapat menggunaka Wong Baker Face Rating dengan rentang nyeri 0 (tidak nyeri) sampai 5 (sangat Nyeri).

Respon nyeri pada anak sangat bervariasi karena dipengaruhi berbagai faktor.Mulai dari Usia anak, jenis kelamin, pengalaman sebelumnya, dan dukungan keluarga berupa pendampingan orang tua. Meski masih diragukan juga bahwa faktor jenis kelamin dapat mempengaruhi rasa nyeri pada anak. Hal ini membuat peneliti untuk melakukan penelitian tentang faktor yang mempengaruhi nyeri pada anak usia 7-13 tahun saat pemasangan infus.

\section{Tujuan Penelitian}

Tujuan penelitian ini untuk mengetahui faktor yang mempengaruhi tingkat nyeri anak usia 7-13 tahun saat di lakukan pemasangan infus di RSUD Kota Makassar.

\section{METODE}

Penelitian ini adalah penelitian kuantitatif dengan menggunakan desaign penelitian observasional analitik dengan rancangan Cross Sectional Study.Penelitian ini dilakukan pada semua anak usia 7-13 tahun di RSUD kota makassar yang mengalami tindakan pemasangan infus dan yang pernah mengalami pemasangan infus sebelumnya dengan jumlah sampel 30 anak.Penelitian ini dilaksanakan Bulan Oktober tahun Desember 2017.Data dianalisis menggunakan uji fisher dengan tingkat kemaknaan $\rho$ value $<0,05$.

\section{HASIL}

\section{Karakteristik Responden}

Tabel 1. Distribusi Responden Berdasarkan Karakteristik Responden

\begin{tabular}{llcc}
\hline & Karakteristik & n & Jumlah \\
\cline { 3 - 4 } Usia & & \% \\
& 7-9 Tahun & 18 & 60 \\
10-13 Tahun & 12 & 40 \\
Jenis Kelamin & & \\
$\quad$ Laki-laki & 16 & 53,3 \\
$\quad$ Perempuean & 14 & 46,7 \\
Pengalaman Sebelumnya & & \\
$\quad$ Pernah & 17 & 56,7 \\
$\quad$ Tidak pernah & 13 & 43,3 \\
\hline
\end{tabular}




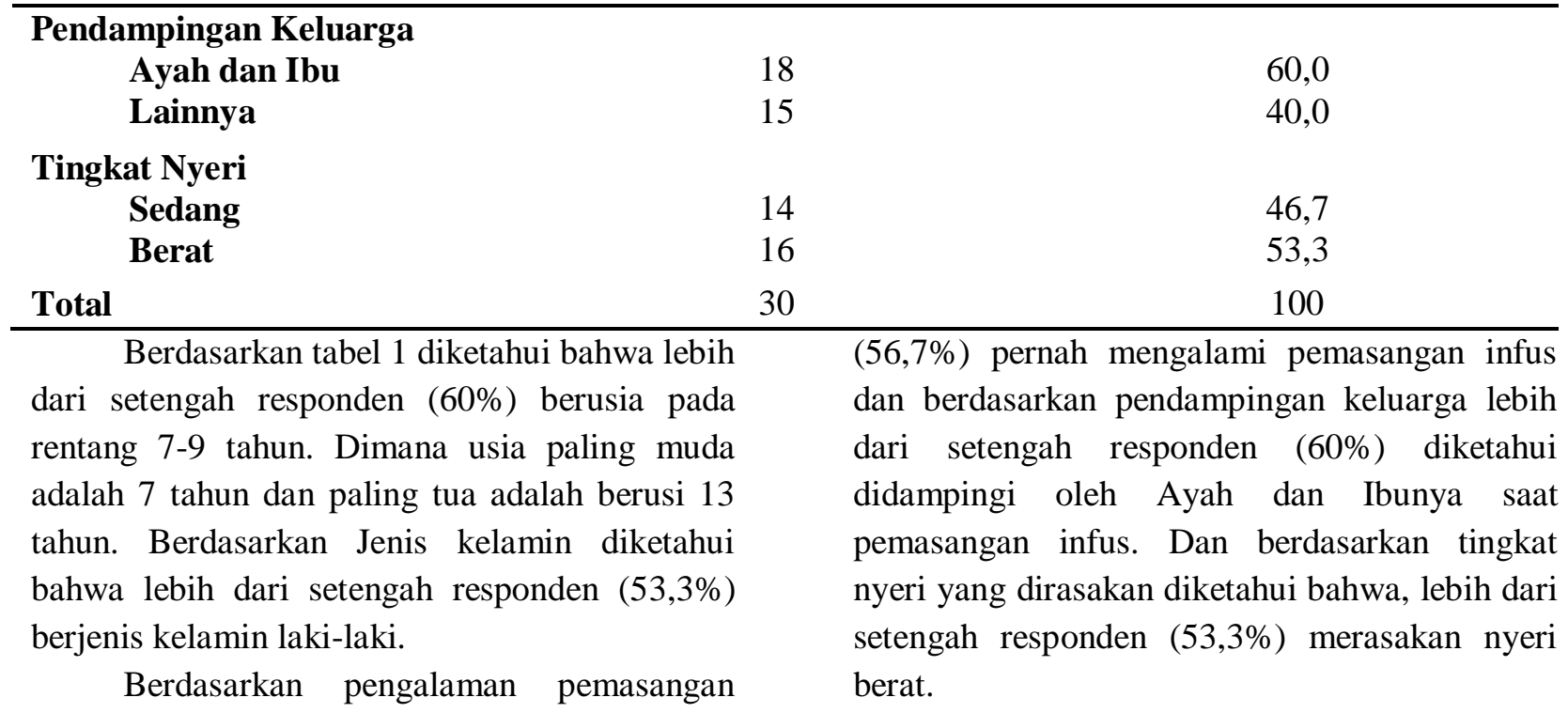

infus, diketahui lebih dari setengah responden

Tabel 2.Pengaruh Jenis Kelamin dengan terhadap Tingkat Nyeri pada Anak Usia 7-13 Tahun saat Pemasangan Infus

\begin{tabular}{|c|c|c|c|c|c|c|c|}
\hline \multirow[t]{3}{*}{ Jenis Kelamin } & \multicolumn{4}{|c|}{ Tingkat Nyeri } & \multirow{2}{*}{\multicolumn{2}{|c|}{ Total }} & \multirow{3}{*}{$\begin{array}{r}\text { Nilai } \rho \\
<0,05\end{array}$} \\
\hline & \multicolumn{2}{|c|}{ Sedang } & \multicolumn{2}{|c|}{ Berat } & & & \\
\hline & $\mathbf{n}$ & $\%$ & $\mathbf{n}$ & $\%$ & $\mathbf{N}$ & $\%$ & \\
\hline Laki-laki & 8 & 50,0 & 8 & 50 & 16 & 100 & 0,730 \\
\hline Perempuan & 6 & 42,9 & 8 & 57,1 & 14 & 100 & \\
\hline Total & 14 & 46,7 & 16 & 53,3 & 30 & 100 & \\
\hline
\end{tabular}

Berdasarkan tabel 2 diketahui bahwa hasil analisi uji fisher menunjukkan bahwa nilai $p=0,730$. Hal ini menunjukkan tidak ada pengaruh yang bermakna antara jenis kelamin terhadap tingkat nyeri pada anak usia 7-13 tahun saat pemasangan infus.

Tabel 3.Pengaruh Pengalaman Sebelumnya terhadap Tingkat Nyeri pada Anak Usia 7-13 Tahun saat Pemasangan Infus

\begin{tabular}{|c|c|c|c|c|c|c|c|}
\hline \multirow{3}{*}{$\begin{array}{l}\text { Pengalaman } \\
\text { Sebelumnya }\end{array}$} & \multicolumn{4}{|c|}{ Tingkat Nyeri } & \multirow{2}{*}{\multicolumn{2}{|c|}{ Total }} & \multirow{3}{*}{$\begin{array}{r}\text { Nilai p } \\
<0,05\end{array}$} \\
\hline & \multicolumn{2}{|c|}{ Sedang } & \multicolumn{2}{|c|}{ Berat } & & & \\
\hline & $\mathbf{n}$ & $\%$ & $\mathbf{n}$ & $\%$ & $\mathbf{N}$ & $\%$ & \\
\hline Pernah & 11 & 64,7 & 6 & 35,3 & 17 & 100 & $\mathbf{0 , 0 3 3}$ \\
\hline Tidak Pernah & 3 & 23,1 & 10 & 76,9 & 13 & 100 & \\
\hline Total & 14 & 46,7 & 16 & 53,3 & 30 & 100 & \\
\hline
\end{tabular}

Berdasarkan tabel 3 diketahui bahwa hasil analisis uji fisher menunjukkan bahwa nilai $p=0,330$. Hal ini menunjukkan ada pengaruh yang bermakna antara pengalaman sebelumnya terhadap tingkat nyeri pada anak usia 7-13 tahun saat pemasangan infus.

Tabel 4.Pengaruh Pendampingan Orang Tua terhadap Tingkat Nyeri pada Anak Usia 7-13 Tahun saat Pemasangan Infus 


\begin{tabular}{|c|c|c|c|c|c|c|c|}
\hline \multirow{3}{*}{$\begin{array}{l}\text { Pendampingan } \\
\text { Orang Tua }\end{array}$} & \multicolumn{4}{|c|}{ Tingkat Nyeri } & \multirow{2}{*}{\multicolumn{2}{|c|}{ Total }} & \multirow{3}{*}{$\begin{array}{c}\text { Nilai } \rho \\
<0,05\end{array}$} \\
\hline & \multicolumn{2}{|c|}{ Sedang } & \multicolumn{2}{|c|}{ Berat } & & & \\
\hline & $\mathbf{n}$ & $\%$ & $\mathbf{n}$ & $\%$ & $\mathbf{n}$ & $\%$ & \\
\hline Ayah dan Ibu & 5 & 27,8 & 13 & 72,2 & 18 & 100 & 0,024 \\
\hline Lainnya & 9 & 75,0 & 3 & 25,0 & 12 & 100 & \\
\hline Total & 14 & 46,7 & 16 & 53,3 & 30 & 100 & \\
\hline
\end{tabular}

Berdasarkan tabel 4 diketahui bahwa hasil analisi uji fisher menunjukkan bahwa nilai $p=0,024$. Hal ini menunjukkan ada pengaruh

\section{PEMBAHASAN}

\section{Karakteristik Responden}

Responden pada penelitian ini berusia 7-13 tahun, dimana menurut teori perkembangan bahwa perkembangan kognitif berada pada tahap kongkret. Dimana anak sudah mampu memngklasifikasi sebuah masalah (Hockenberry, \& Wilson, 2009) dan seiring perkembangan dan pertambahan usia, anak akan belajar menggunakan kata untuk menjelaskan nyeri mereka secara utuh (Kyle \& Carman, 2012).

Faktor-faktor yang dianggap mempengaruhi tingkat nyeri pada anak dalam penelitian ini adalah jenis kelamin, pengalaman sebelumnya dan pendampingan orang tua.

\section{Pengaruh Jenis Kelamin terhadap Tingkat Nyeri Anak Usia 7-13 Tahun saat Pemasangan Infus}

Berdasarkan jenis kelamin, diketahui bahwa tidak ada pengaruh yang bermakna dengan tingkat nyeri pada anak usia 7-13 tahun saat pemasangan infus. Penelitian ini sejalan dengan penelitian Sulistiyani (2009) yang meneliti pengaruh kompres es terhadap tingkat nyeri saat pemasangan infus menyatakan bahwa tidak ada perbedaan proporsi tingkat nyeri antara anak pra sekolah yang berjenis kelamin laki-laki dan perempuan yang yang bermakna antara pendampingan orang tua terhadap tingkat nyeri pada anak usia 7-13 tahun saat pemasangan infus.

dilakukan pemasangan infus.Meskipun dalam penelitian ini, lebih dari setengah responden adalah berjenis kelamin lakilaki.

Hasil tidak sesuai dengan penelitian sebelumnya bahwa anak lakilaki lebih dapat menolerasi terhadap rasa sakit (Ramadhan, Susilaningsih, \& Zulaicha, 2018).Menurut teori bahwa lakilaki memiliki perbedaan dalam mengespresikan rasa nyeri yang dialami.Namun pada dasarnya toleransi terhadap nyeri dipengaruhi oleh faktorfaktor biokimia dan merupakan hal unik pada setiap individu tanpa memperhatikan jenis kelamin(Perry \& Potter, 2005).

\section{Pengaruh Pengalaman Sebelumnya terhadap Tingkat Nyeri Anak Usia 7-13 Tahun saat Pemasangan Infus}

Berdasarkan pengalaman sebelumnya, diketahui bahwa ada pengaruh yang bermakna antara pengalaman sebelumnya denga tingkat nyeri anak usia 7-13 tahun saat pemasangan infus. Hal ini membuktikan bahwa pengalaman sebelumnya akan membuat anak berusaha untuk beradaptasi terhadap nyeri (Potter \& Perry, 2010). Dimana dari pengalaman peneliti, didapatkan bahwa lebih banyak responden yang penah mengalami pemasangan infus sebelumnya. 
Sejumlah kejadian nyeri, jenis nyeri dan intensitas pengalaman nyeri sebelumnya termasuk cara anak dalam merespon nyeri akan mempengaruhi bagaimana anak bisa menerima nyeri saat ini. Sehingga, pengalaman nyeri di masa lalu dengan pengendalian nyeri yang tidak adekuat menyebabkan peningkatan distres selama prosedur yang dapat menimbulkan nyeri di masa yang akan dating (Kyle \& Carman, 2012). Penelitian ini sesuai dengan penelitian sebelumnya yang menunjukkan bahwa proporsi pengalaman pemasangan infus sebelumnya sebesar 53,6\% (Maryam, 2013). Namun pengalaman nyeri sebelumnyatidak selalu berarti bahwa seseorang akan menerima nyeri lebih mudah pada masa yang akan datang (Potter \& Perry, 2009).

\section{Pengaruh Pendampingan Orang Tua terhadap Tingkat Nyeri Anak Usia 7-13 Tahun saat Pemasangan Infus}

Faktor lainnya adalah pendampingan orang tua, dimana dari hasil penelitian menunjukkan ada pengaruh yang bermakna antara pendampingan orang tua terhadap tingkat nyeri pada anak usia 7-13 tahun saat pemasangan infus.Seluruh responden saat dilakukan pemasangan infus didampingi oleh keluarga yang didominasi oleh kehadiran kedua orang tua (ayah dan ibu) sebesar 18 responden (60\%).Penelitian ini sejalan dengan penelitian yang dilakukan oleh (Maryam, 2013) yang mendapatkan bahwa proporsi pendampingan orang tua/ibu yaitu sebesar $78,6 \%$. Kedekatan ibu dengan anaknya akan memberikan ketenangan bagi anak karena kenyamanan pada anak juga akan dipengaruhi oleh kenyamanan psikologis dan sosiokultural (Kolcaba \& DiMarco, 2005).
Kehadiran orang tua sangat penting bagi anak-anak yang sedang mengalami suatu tindakan yang menimbulkan nyeri (Hockenberry, \& Wilson, 2009). Jika rasa nyaman anak terpenuhi maka anak akan kooperatif, tidak menangis selama tindakan dan nyeri menurun (Kolcaba \& DiMarco, 2005). Memisahkan anak dengan orang tua saat melakukan tindakan prosedur akan menyebabkan anak lebih trauma dan memberikan ingatan yang lebih negative, sehingga sangat penting kehadiran orang tua terutama ibu saat anak dilakukan pemasangan infus.

Sebegitu pentingnya pendampingan dan peranan orang tua dalam mengasuh anak, sebagaimana hal tersebut dijelaskan dalam suratAn-Nisa ayat 9 yang artinya "Dan hendaklah takut kepada Allah orang-orang yang seandainya meninggalkan di belakang mereka anak-anak yang lemah, yang mereka khawatir terhadap (kesejahteraan) mereka. Oleh sebab itu hendaklah mereka bertakwa kepada Allah dan hendaklah mereka mengucapkan perkataan yang benar(Qs.An-nisa : 09).”

Surat an-Nisa' ayat 09 ini menerangkan bahwa setiap orang tua hendaknya merasa khawatir jika meninggalkan keturunanya dalam keadaan lemah, mewujudkan generasi berkualitas merupakan tanggung jawab orang tua, dan bekal yang paling utama disediakan pada generasi muda adalah taqwa dan pendidikan yang baik. Dengan demikian peranan orang tua dalam segala hal begitu berarti.

\section{PENUTUP}

\section{Kesimpulan}

Umur responden antara umur 7-13 tahunyang banyak berjenis kelamin laki- 
laki.Lebih dari setengah responden memiliki pengalaman pemasangan infus sebelumnya.Saat responden dilakukan tindakanpemasangan infus selalu didampingi olehkeluarga dan didominasi oleh kehadiranibu dan ayah.

Hasil penelitian menunjukkan tidak ada pengaruh jenis kelamin terhadap tingkat nyeri

\section{DAFTAR PUSTAKA}

Andarmoyo, S. (2013). Konsep dan proses keperawatan nyeri. Jogjakarta: Arruz Media.

Hidayat, A. A. (2005). Pengantar ilmu keperawatan anak 1. Jakarta : selemba medika.

Hockenberry,, M. J., \& Wilson, D. (2009). Wong's essentials of pediatric nursing. (8 th ed). Mosby Elseiver.

Kolcaba, K., \& DiMarco, M. (2005). Comfort theory and its application to pediatric nursing. Pediatrc Nursing,.

Kyle, T., \& Carman, S. (2012). Buku Ajar Keperawatan Pediatri, Ed 2, Vol. 2. Jakarta: Buku Kedokteran EGC.

Andarmoyo, S. (2013). Konsep dan proses keperawatan nyeri. Jogjakarta: Arruz Media.

Hidayat, A. A. (2005). Pengantar ilmu keperawatan anak 1. Jakarta : selemba medika.

Hockenberry,, M. J., \& Wilson, D. (2009). Wong's essentials of pediatric nursing. (8 th ed). Mosby Elseiver.

Kolcaba, K., \& DiMarco, M. (2005). Comfort theory and its application to pediatric nursing. Pediatrc Nursing,.

Kyle, T., \& Carman, S. (2012). Buku Ajar Keperawatan Pediatri, Ed 2, Vol. 2. Jakarta: Buku Kedokteran EGC.

Marimbi. (2010). Tumbuh Kembang, Status Gizi dan Imunisasi Dasar Balita. Yogyakarta: Nuha Medika.

Maryam. (2013). Tingkat Nyeri Anak Usia 7 13 Tahun saat dilakukan Pemasangan anak usia 7-13 tahun saat pemasangan infus. Namun, ada pengaruh pengalaman sebelumnya dan pendampingan orang tua terhadap tingkat nyeri anak usia 7-13 tahun saat pemasangan infus.

Infus di RSUD Kota Semarang. Jurnal Keperawatan Anak Volume 1. No 1, 18 23.

Potter, P.A. \&Perry, A.G.,(2005).Fundamental of nursing: Concepts,process, and practice. (6th ed). St.Louis:Mosby

Potter, P. A., \& Perry, A. G. (2009). Fundamental Keperawatan, Edisi 7 Buku 2. Jakarta: Salemba Medika.

Potter, P., \& Perry, A. (2010). Buku Ajar Fundamental Keperawatan. (Adrina Ferderika $N$ editor Bahasa Indonesia). 7th ed. Jakarta: Selemba Medika.

Ramadhan, M. I., Susilaningsih, \& Zulaicha, K. (2018). Gambaran Respon Nyeri Pada Anak Saat Pemasangan Infus Di Instalasi Gawat Darurat (IGD) RSUD Dr. Moewardi Surakarta.

Sulistiyani, Endah. (2009). Pengaruh Pemberian Kompres Es Batu terhadap Tingkat Nyeri pada Anak Usia Pra Sekolah yang Dilakukan Prosedur Pemasangan Infus di Rumah Sakit Umum Pusat dr. Cipto Mangunkusumo Jakarta. Tesis. Program Magister Ilmu Keperawatan Anak Universitas Indonesia: Jakarta.

Wang, Z. X., Sun, L., \& Chen, A. P. (2008). The efficacy of nonpharmacological methods of pain management in school age children receiving venepuncture in a pediatric department: A randomized controlled trial of audiovisual istractin and routine psychological intervention. Swiss Med WKLY, 138 (39-40), 579 584. 